\author{
WOJCIECH HOFMAŃSKI \\ (D) https://orcid.org/0000-0003-4902-0945 \\ Uniwersytet im. Adama Mickiewicza \\ Poznań
}

\title{
Śląszczyzna \\ w perspektywie współczesnych metod badawczych. Postępy i postulaty
}

\begin{abstract}
Silesian from the point of view of contemporary research methods.
Progress and postulates
\end{abstract}

\begin{abstract}
The paper attempts to discuss the Silesian ethnolect from two different points of view. The first one is determined by the current status of research, including above all the identifiable areas of shortcomings in the field. The other goes beyond the Polish perspective that prevails in the Silesian studies discourse. The author discusses the progress of work on a Silesian language corpus, interactive research into Slavic languages in the context of intercomprehension, as well as the matched-guise technique, potentially making it possible to assess the perception of the Silesian ethnolect in the area where it is present. The research scopes indicated are considered to be of key importance in the context of the description of the condition and status of the ethnolect. Key words: Silesian ethnolect, linguistics, sociolinguistics, intercomprehension, the matches-guise technique
\end{abstract}

Niniejszy artykuł jest próbą spojrzenia na problem śląszczyzny ${ }^{1}$ z dwóch

\footnotetext{
${ }^{1}$ Ponieważ celem niniejszej publikacji nie jest próba odpowiedzi na pytanie o status śląszczyzny, a jedynie wskazanie niezbędnych w tym zakresie badań i prac wraz z uzasadnieniem ich znaczenia oraz opisem ewentualnego zaawansowania, pojęcie śląs zc zy zny będzie stosowane wymiennie z pojęciem etnolekt. Jednocześnie, unikając jednoznacznego opowiadania się za językową lub dialektologiczną interpretacją śląszczyzny, przyjmuję za Jiř́m Nekvapilem, Mariánem Slobodą i Petrem Wagnerem relatywnie neutralną definicję etnolektu jako kodu, którym mówią członkowie narodowościowych czy etnicznych mniejszości. Przy czym - według praskich językoznawców - jest to również określony typ (wariant) języka większościowego, charakteryzujący się tym, że zawiera ślady języka mniejszościowego, którym posługiwali się rodzice czy dziadkowie osób posługujących się dziś etnolektem (Nekva-
} 
odmiennych, choć - jak się wydaje - przynajmniej częściowo nakładających się perspektyw. Pierwszą wyznacza aktualny stan badań, a przede wszystkim możliwe do zidentyfikowania i wskazania obszary niedokonań w tym zakre$\mathrm{sie}^{2}$. Druga perspektywa wykracza natomiast poza dominujący w dyskursie silezjanistycznym polski punkt odniesienia. W praktyce oznacza to, że metodologicznie ukierunkowane myślenie o specyfice komunikacji osób wskazujących śląszczyznę jako język codziennego porozumiewania się w oficjalnych opracowaniach wyników narodowych spisów powszechnych ${ }^{3}$ powinno uwzględniać nie tylko szersza, niepolonocentryczną optykę, ale równolegle paradygmatyczne zmiany dokonujące się w zakresie szeroko rozumianej lingwistyki.

Brak regulacji prawnych określających status śląszczyzny przy jednoczesnym postulowaniu przez część środowiska naukowego i niektórych działa-

pil, Sloboda, Wagner 2009, 45), co ze względu na historyczne interakcje językowe na terenie Górnego Śląska wydaje się wystarczającym uzasadnieniem.

2 Ze względu na wyraźnie ograniczony rozmiar analizy nie podejmę się przy okazji wstępnego nakreślania problemu precyzyjnego odtworzenia aktualnego stanu badań i przeglądu problemów poruszanych przez wiodących badaczy śląskości. Ograniczając się - zgodnie z celem szczegółowym artykułu - do wskazania i uzasadnienia wyboru najważniejszych wyzwań stojących przed krystalizująca się silezjanistyką z perspektywy lingwistycznej, trzeba jednak z całą moca podkreślić znaczenie dorobku szeregu badaczy reprezentujących różne dyscypliny. W tym zakresie na szczególną uwagę zasługują prace Jolanty Tambor (2006, 2015), Ewy Michny (2008, 2014, 2015), Marii Szmei (2017), Karoliny Pospiszil (2016), Zbigniewa Kadłubka (2008, 2011), Artura Czesaka (2008), Bogusława Wyderki (2014).

${ }^{3}$ Choć w 2002 roku narodowość śląską deklarowały aż 173153 osoby, w codziennej, nieoficjalnej komunikacji etnolektem śląskim posługiwało się znacznie mniej badanych. Co ciekawe, na 56643 deklarujących to respondentów narodowość śląską zasygnalizowało tylko 29345 . W praktyce oznacza to, że w grupie użytkowników etnolektu śląskiego jedynie $52 \%$ badanych identyfikowało siebie jako Ślązaków. Jednocześnie aż 19991 osób wskazało tu narodowość polska. Pozostałe osoby (7213) zadeklarowały zaś przede wszystkim narodowość niemiecka, co przekładało się na niespełna 13\% użytkowników tego kodu (por. http://stat. gov.pl/spisy-powszechne/narodowe-spisy-powszechne/narodowy-spis-powszechny-2002/wy niki-narodowego-spisu-powszechnego-2002-narodowosci-oraz-jezyka/ [dostęp: 15.08.2018]). W opracowaniu wyników kolejnego spisu powszechnego z 2011 roku zwraca uwagę wzrost liczby osób narodowości śląskiej. Wśród wskazujących ją respondentów (847 000) mniej niż połowa deklarowała śląskość jako jedyną (376 000). Jednocześnie aż 431000 wskazało narodowość śląską łącznie z polską (por. http://stat.gov.pl/spisy-powszechne/nsp-2011/nsp2011-wyniki-wstepne/przynaleznosc-narodowo-etniczna-ludnosci-nsp-2011,1,1.html [dostęp: 15.08.2018]). Jednocześnie w 2011 roku w kontaktach domowych - zgodnie z zaznaczanymi wyborami - śląszczyzną posługiwało się aż 529377 osób (por. http://stat.gov.pl/spisy-po wszechne/nsp-2011/nsp-2011-wyniki/wybrane-tablice-dotyczace-przynaleznosci-narodowoet nicznej-jezyka-i-wyznania-nsp-2011,8,1.html [dostęp: 15.08.2018]). 
czy kulturowych ${ }^{4}$ konieczności uznania tego kodu za odrębny język naturalnie ukierunkowuje toczącą się dyskusję na tor, który prowadzi na północ od Śląska - do decyzyjnego centrum politycznego w Warszawie. Tymczasem wydaje się pewne, że dopiero pełny obraz obecnego stanu rzeczy zapewni szersze spojrzenie z zewnątrz. Niewątpliwie wiele cennych obserwacji można poczynić, analizując działania prowadzone w zakresie ochrony dziedzictwa kultury niematerialnej Serbów Łużyckich. Taka analogia, uwzględniająca nawet fakt współwystępowania germanizmów, a także intensywne eksploatowanie obu górniczo-przemysłowych regionów, może jednak błędnie zamykać koło mniejszościowe. Częściowo tabuizowana na gruncie polskim problematyka autoidentyfikacji rodowitych mieszkańców Śląska nie ułatwia bowiem prowadzenia rzeczowych dyskusji na ten temat. Wiązana z tym polityka językowa jest jednak polityką w pełnym zakresie tego słowa - opartą na symbolizmie, pragmatyzmie i zimnej kalkulacji, nie na naukowych przesłankach i fachowych opiniach specjalistów-językoznawców. Zaledwie kilkudziesięciotysięczna mniejszość łużycka ${ }^{5}$, zamieszkująca pierwotnie teren odkrywkowych kopalń węgla brunatnego, stopniowo rozpływa się w niemieckim substracie. Polityka energetyczna Niemiec również sprzyja przychylnemu spojrzeniu na sprawy łużyckie. Tymczasem polski kontekst śląskiej problematyki wciąż nazbyt łatwo napotyka na mur strategicznego znaczenia złóż węgla kamiennego, za którym znajdują się obawy wręcz uniemożliwiające pozbawiony emocji i rzeczowy dialog. Dodatkowe trudności z wytyczeniem

\footnotetext{
${ }^{4} \mathrm{Na}$ odnotowanie zasługuje w tym kontekście konferencja „Śląsko godka - jeszcze gwara czy jednak już język?”, która odbyła się 10 czerwca 2008 roku w Sali Sejmu Śląskiego. W wydarzeniu wzięło udział ponad 250 osób o różnych afiliacjach, profesjach i poglądach. Po dziesięciu latach, w nawiązaniu do konferencji z 2008 roku, Regionalny Instytut Kultury w Katowicach wraz z Instytutem Języka Polskiego im. Ireny Bajerowej UŚ oraz Centrum Badań nad Kulturami Mniejszymi UŚ zorganizował kolejną edycję pod hasłem „Śląsko godka już język czy jeszcze gwara?” (27.04.2018 r.), w której jako prelegenci udział wzięli m.in.: prof. dr hab. Tomasz Wicherkiewicz, dr hab. Ewa Michna, Jerzy Ciurlok czy Alojzy Łysko. Obie konferencje były organizowane i prowadzone przez prof. dr hab. Jolantę Tambor.

${ }^{5} \mathrm{Nie}$ istnieje pewne źródło, na którym można oprzeć tego typu precyzyjne wskazania. Wynika to przede wszystkim z faktu, że współczesny niemiecki standard spisów powszechnych nie zawiera pytań odnoszących się do przynależności etnicznej (dane z 1987 roku wskazują przy tym na 67 tys. osób deklarujących posługiwanie się językiem łużyckim i 45 tys. osób określających siebie mianem Łużyczan). Jednocześnie organizacje takie jak Domowina posługują się własnymi szacunkami, które jednak - z tych samych powodów - są nieweryfikowalne, a jednocześnie istnieje ryzyko braku obiektywizmu. Osobnym problemem jest także metodologia - przyjęte kryteria (językowe, etniczne, autoidentyfikacyjne czy mieszane) istotnie zmieniają obraz sytuacji panującej na Łużycach (por. Niedźwiecka 2009, 82).
} 
takiej analogii potęguje także fakt, że systemowa bliskość dzieląca polszczyznę od potencjalnie niezależnej śląszczyzny nie przekracza granicy rodziny językowej, jak ma to miejsce w przypadku praktycznie bilingwalnych Serbów Łużyckich, operujących językami niespokrewnionymi przy uwzględnieniu całkowicie odmiennego zakresu funkcjonalnego obu kodów.

Poszukiwanie odpowiednich analogii można zatem rozpocząć od ruchu w przeciwną do północy stronę. Problem standaryzacji i uznawalności języków słowiańskich nie jest przecież problemem nowym. Nowoczesna polityka językowa, regulująca status kaszubszczyzny - podobnie jak choćby języka górno- i dolnołużyckiego - rozwiązuje szereg problemów, które jednak już wcześniej były pokonywane innymi metodami. Podobieństwo tych problemów jest przy tym uderzające. Dzisiejsza Republika Czeska to ponaddziesięciomilionowy kraj, którego mieszkańcy posługują się na co dzień czeszczyzna - językiem rekonstruowanym od połowy XIX wieku na fali odrodzenia narodowego. Dzisiejsze prace nad śląszczyzną, mimo upływu półtora wieku, rodzą więc natychmiastowe skojarzenia z dorobkiem Dobrovskiego czy Jungmana i ich następców. Znakiem czasu jest jedynie to, że w kluczowym dla przetrwania etnolektu momencie tradycyjną formę słownikową zastępuje nieporównywalnie bardziej praktyczny korpus. W obu przypadkach stało się bowiem coś, co nie ma przełożenia na sytuację łużycką czy kaszubską, a co jednocześnie sprowadzić można - w ogromnym uproszczeniu - do przynajmniej częściowego zaniku stygmatu prowincjonalizmu ${ }^{6}$. Niesiona falą odrodzenia narodowego praska inteligencja - podobnie jak współcześni mieszkańcy ponaddwumilionowej aglomeracji górnośląskiej - zyskała „urbanistyczny” komfort, którego znaczenia w kontekście socjolingwistycznym nie sposób przecenić. To właśnie ten aspekt uznać można za kluczowy czynnik warunkujący nie tylko niełatwy proces standaryzacji, ale również dalszy rozwój.

Będący na ukończeniu - choć jeszcze nieudostępniony ${ }^{7}$ - śląski korpus (Korpus ślōnskij mowy), który od lutego 2017 roku samodzielnie opracowu-

\footnotetext{
${ }^{6}$ Osobnym zagadnieniem - wymagającym także dalszych, odrębnych badań socjologicznych - byłby problem ewentualnego poczucia plebejskości czy proletariackości, mogący w nieco odmienny sposób wpływać na konstrukt tożsamości rodowitych mieszkańców Górnego Śląska.

7 Projekt Grzegorza Kulika „Finalizacja opracowania Korpusu Śląskiej Mowy” w 2018 roku zyskał wsparcie finansowe w ramach konkursu na stypendia w dziedzinie kultury organizowanego na podstawie Strategii rozwoju kultury w wojewódz̨twie ślaskim na lata 2006-2020 oraz uchwały Sejmiku Województwa Śląskiego nr I/49/13/2002.
} 
je Grzegorz Kulik, jest katalogiem unikatowym. W chwili obecnej zawiera 8874500 słowoform, co przekłada się na 180839 typów słów, czyli posiadających różne znaczenie (względnie uzasadnioną, odmienną postać formalna) jednostek ${ }^{8}$. Podstawa materiałowa została zgromadzona w 150 katalogach, które ostatecznie rozdzielone zostaną na pojedyncze teksty źródłowe - w ten sposób odrębny katalog tworzy np. zbór dialektologicznych transkrypcji tekstów gwarowych. Zakres chronologiczny również imponuje. Najstarszy tekst pochodzi z 1574 roku9. Dwa kolejne przypadaja na lata 1650 i 1820 . Gwałtowny wzrost liczby tekstów źródłowych przypada zaś na 1856 rok.

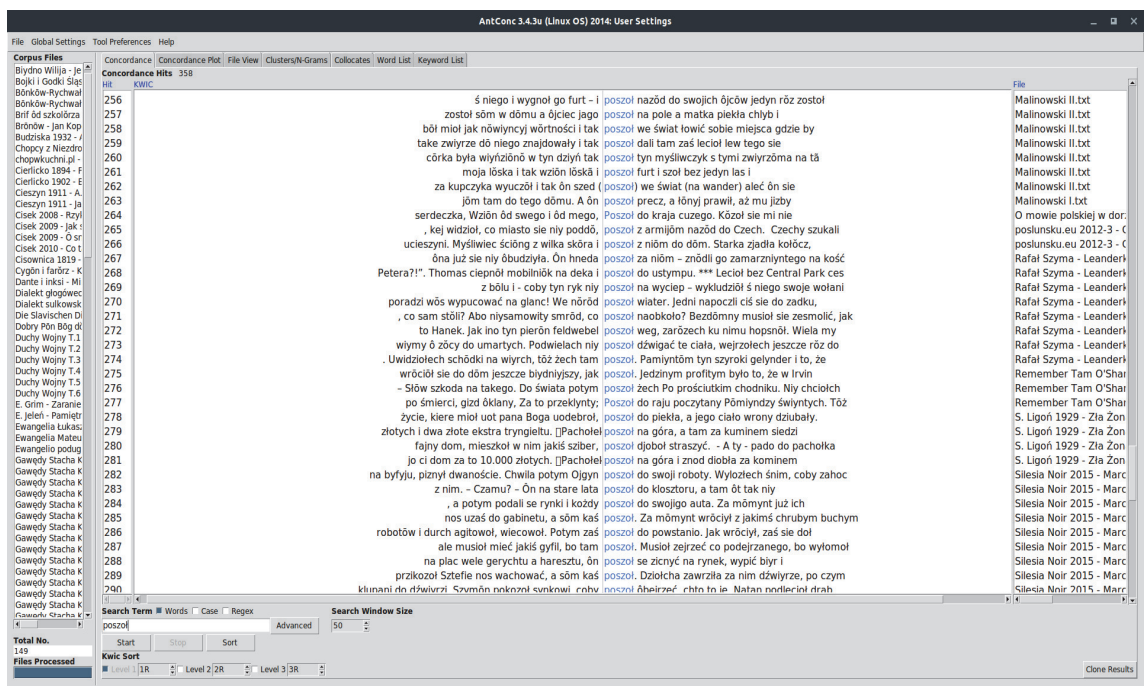

Obraz 1. Przykład wyszukiwania dla hasła „poszoł” (PrtSc).

Zasięg geograficzny obejmuje praktycznie cały teren Górnego Śląska. Niedostatki są jednak notowane w odniesieniu do rejonu Góry Świętej Anny. Na korpus składają się nietranskrybowane - już pierwotnie opracowane w standardzie ślabikŏrza, czyli ustandaryzownym śląskim zapisie - teksty literackie (m.in. tłumaczenia Małego Księcia Antoine’a de Saint-Exupéry’ego, Dracha Szczepana Twardocha, ale także dzieła oryginalne, jak choćby krymi-

${ }^{8}$ Dane dotyczą wersji na dzień 2.08.2018 r.

9 Jest to list Ambrożego Sklorza z Olesna, w którym skarży się możnowładcy - zapewne księciu legnicko-brzeskiemu Jerzemu II (panującemu w latach 1547-1586) - na problemy z uzyskaniem należnej mu części spadku. 
nały Marcina Melona). Kolejna grupę stanowią transkrybowane teksty gwarowe. Ta kategoria przekłada się na 270328 słowoform. Współczesny język reprezentują teksty prasowe. W tej kategorii odnaleźć można publicystykę $\mathrm{i}$ informacje publikowane po śląsku na portalu Wachtyrz.eu (około 350 artykułów przekładających się na 23000 słowoform). Całość uzupełniają teksty z „Gościa Niedzielnego” (z lat 1924-52) oraz „Kocyndra”10. Niestety, w obecnym stanie korpus praktycznie nie zawiera katalogu współczesnych tekstów będących realizacjami odmiany mówionej, co jednocześnie wydaje się naturalnym kierunkiem jego rozwoju.

Współczesna lingwistyka komputerowa wspomagana zapleczem korpusowym rozwija również nowoczesne narzędzia translacyjne. Równoległym więc do korpusu projektem jest opracowywany również przez Grzegorza Kulika automatyczny polsko-śląski translator. W przeciwieństwie do najpopularniejszego translatora Google nie jest to narzędzie statystyczne, ale preskrybowane, co zapewnić ma znacznie większą precyzję przekładu, dzięki jednoznacznie zweryfikowanym i przyporządkowanym informacjom o leksykalnych odpowiednikach i regułach ich łączenia. Oczywistym zapleczem jest przy tym wciąż rozbudowywany korpus.

Widoczne także w badaniach korpusowych zainteresowanie autentycznym użyciem języka wiązać można ze zwrotem kognitywnym w światowej lingwistyce. Przesunął on bowiem akcent na to, co umożliwiło współczesnej slawistyce prowadzenie badań w obszarach niebędących dotąd w centrum zainteresowania strukturalistów ${ }^{11}$. Warto zatem, wraz z postępującą standaryzacją śląszczyzny dostępnymi już narzędziami weryfikować jej komunikacyjny potencjał w rodzimej, słowiańskiej przestrzeni językowej. Tego typu prac na gruncie slawistycznym podjęła się w latach 2011-2016 pracująca nad fenomenem interkomprehensji holenderska profesor Charlotte Gooskens z zespołem. Dla olbrzymiego projektu „Mutual intelligibility of closely related

10 „Kocynder” to górnośląski miesięcznik o charakterze humorystyczno-satyrycznym, wychodzący po śląsku oraz po polsku w latach 1920-1939 i 1946-1958.

11 Przykładem tej perspektywy badawczej w zakresie slawistycznym w polskim środowisku akademickim jest choćby monumentalna monografia Hanny Dalewskiej-Greń (1997) Jezyki słowiańskie, która mimo niezwykle szczegółowych zestawień (uwzględniających system spółgłoskowy i samogłoskowy, prozodię, strukturę sylaby, kwestię akomodacyjnego typu wymowy, alternacje fleksyjne, kategorie morfologiczne, paradygmatykę, modalność, negację, paradygmaty diatetyczne, układ linearny wypowiedzeń, postaci wyrażenia predykatywnego, wyrażenia argumentowe, formalizację struktur polipredykatywnych, a nawet zagadnienia związane z kształtowaniem się narodowych literackich języków słowiańskich oraz współcześnie używanych systemów pisowni) nie odnosi się do zagadnień komunikacyjnych i interreakcyjnych. 
languages in Europe: linguistic and non-linguistic determinants" punktem wyjścia był model opracowany dla standardowych języków skandynawskich. Oczekiwano bowiem, że model ten będzie miał zastosowanie do kombinacji ściśle powiązanych języków i odmian językowych poza Skandynawią, a wyniki zwiększą ogólne rozumienie roli odległości językowej we wzajemnej zrozumiałości (interkomprehensji, komunikatywności) blisko spokrewnionych języków ${ }^{12}$.

W odniesieniu do języków słowiańskich na szczególną uwagę zasługują wyniki badań zaprezentowane po czterech latach od rozpoczęcia prac. Wykorzystując autorskie testy wzajemnej zrozumiałości blisko spokrewnionych języków, badaczki oszacowały stopień możliwego porozumienia w odniesieniu do języka w wariancie pisanym oraz mówionym. Wczesny etap rozpowszechniania standardu pisanego śląszczyzny - ślabikŏrza - skłania w tym punkcie do szczególnego zainteresowania drugim z badanych przez Jelenę Golubović oraz Charlotte Gooskens aspektów. Udało się bowiem ustalić, że

użytkownicy języka czeskiego, słowackiego i polskiego zdobyli lepsze wyniki w innych językach zachodniosłowiańskich w porównaniu z chorwackim czy słoweńskim. W odniesieniu do danych południowosłowiańskich pojawił się jednak interesujący fakt. Użytkownicy chorwackiego i słoweńskiego mogą rozumieć zarówno czeski, jak i słowacki (języki zachodniosłowiańskie) lepiej niż rozumieją bułgarski, który jest także językiem południowosłowiańskim. Najwyższe wyniki testu pisemnego uzyskali użytkownicy języka słowackiego, słuchając czeskiego (99,63\%), użytkownicy czeskiego, słuchając słowackiego (97,33\%), użytkownicy słoweńskiego, słuchając chorwackiego $(94,14 \%)$ i użytkownicy chorwackiego, słuchając słoweńskiego (63,89\%) (Golubović, Gooskens 2015, 364 - tłum. W.H.).

Wpisanie śląszczyzny w interreakcyjny kontekst wydaje się przy tym niezwykle cenne, choć również stosunkowo trudne. Metodologia takich badań musiałaby bowiem uwzględniać fakt, że poddawani komunikacyjnym eksperymentom użytkownicy śląszczyzny są osobami praktycznie bilingwalnymi ${ }^{13}$,

\footnotetext{
12 Pełny opis dostępny jest na stronie macierzystej projektu: http://www.let.rug.nl/goos kens/?p=project [dostęp: 31.07.2018].

13 Pojęcie bilingwizmu (multilingwizmu, wielojęzyczności) jest w niniejszym opracowaniu traktowane niezwykle ogólnie - jako fenomen związany z wymiennym wykorzystywaniem dwóch lub większej liczby języków (i/lub jego wariantów regionalnych) przez tę samą osobę. Szczegółowe rozważania na temat charakteru tego fenomenu w kontekście śląskim wymaga-
} 
które swobodnie funkcjonują także w polskiej rzeczywistości językowej. Fakt ten niewatpliwie utrudnia bezpośrednie badanie komunikacyjnego potencjału śląszczyzny w perspektywie zainteresowania stopniem symetrii. Nie przekreśla to jednak innych badań o charakterze komparatywnym, w których porównywano by nie relacje śląszczyzny z innym językiem słowiańskim, ale ocenę subiektywnie postrzeganego stopnia trudności rozumienia czy obiektywnych możliwości poprawnego reagowania na bodziec komunikacyjny bez uwzględniania stopnia symetrii, ale wyłącznie „na zewnątrz”. Tego typu prace zostały już przeprowadzone w zakresie czesko-polskim (Hofmański 2014, 83-89). W ten sposób za pomocą istniejącej już metodologii można nakreślić mapę ilustrującą zmiany rozumienia i postrzegania śląszczyzny w kolejnych regionach zamieszkałych przez słowiańskojęzyczne społeczności ${ }^{14}$, ustalając jej pozycję nie tylko w odniesieniu do języka polskiego, ale do innych języków, z którymi możliwa jest interkomprehensyjna interakcja.

Wydaje się jednak, że stworzenie korpusu dającego szasnę wielopłaszczyznowych analiz systemowych i uzualnych na znacznej partii materiału językowego oraz zweryfikowanie potencjału komunikacyjnego śląszczyzny w kontaktach interkomprehensyjnych z językami najbliżej spokrewnionymi nie wyczerpuje listy najważniejszych wyzwań stojących aktualnie przed lingwistami zainteresowanymi statusem, a także funkcjonowaniem i miejscem śląszczyzny w (zachodnio-)słowiańskiej przestrzeni językowej. Przywoływany już czeski kontekst badań nad śląszczyzną kolejny raz zyskuje na znaczeniu, jeśli sytuację językową w kraju południowych sąsiadów potraktuje się w kategoriach twórczej inspiracji. Silnemu zróżnicowaniu regionalnemu czeszczyzny towarzyszy bowiem zjawisko niemające bezpośredniego odpowiednika w Polsce. Obok bowiem występującej również na gruncie języka polskiego opozycji normy wzorcowej do normy użytkowej (spisovná čeština: hovorová čeśtina) dostrzega się fakt funkcjonowania trzeciej warstwy, którą

łyby jednak przytoczenia kolejnych teoretycznych modeli (por. Murrmann 2014) oraz odnoszenia ich kolejno do specyfiki i wewnętrznego zróżnicowania sytuacji językowej Śląska. Temat ten ze względu na swoją rangę oraz samą objętość analizy powinien zostać podjęty w oddzielnym opracowaniu.

${ }^{14}$ Wskazanie regionów, a nie krajów czy języków ma na celu podkreślenie faktu, że tego typu badania moga (a na późniejszym etapie prac wręcz powinny) uwzględniać sytuację dialektologiczna języka docelowego (języków docelowych), który zestawiany jest ze śląszczyzną. Tym samym badania na terenie Rep. Czeskiej zestawiałyby porównawczo np. wyniki uzyskane na terenie Moraw, Śląska i Czech. 
stanowi ekspansywny interdialekt (obecná čeština), będący konsekwencją ciągłego rozwijania się regionalnych wariantów środkowoczeskich równolegle do rozprzestrzeniania się zrekonstruowanego w XIX wieku języka (zob. Siatkowska 1992, 6-7; Balowska 2006). Większe zainteresowanie czeskich językoznawców postawami wobec języka (m.in. Bajerová-Nerlichová 2004; Daneš 1999; Nerlich 2009) nie powinno zatem dziwić.

Watpliwości co do autentycznych poglądów użytkowników na temat wykorzystywanego przez nich języka może rodzić ryzyko dostosowywania odpowiedzi do zakładanych przez informatorów oczekiwań badaczy, a także chęć lepszego zaprezentowania własnej osoby przez wskazanie kodu subiektywnie uważanego za bardziej prestiżowy. Efektem takich procesów jest, rzecz jasna, niemiarodajność wyników. Odpowiedzią na ten problem okazuje się te chnika przybieranych mase k (czes. technika spojitých masek, ang. matched-guise technique ${ }^{15}$ ) prawdopodobnie pierwszy raz omówiona na gruncie środkowoeuropejskiego językoznawstwa przez czeskiego lingwistę Jana Chromego (2009). Do podstawowych założeń tej metody weryfikowania postaw wobec języka należy bowiem nieuświadamianie uczestnikom eksperymentu przedmiotu badania -

Samo badanie wygląda następująco. TO [testowane osoby - W.H.] instruuje się, aby w przygotowanym kwestionariuszu ocenily cechy osobowościowe autorów poszczególnych wypowiedzi, przy czym TO nie wiedza, że każdy autor wypowiedział się dwukrotnie (myśli, że chodzi o dziesięć różnych osób). Zakłada się, że TO obie maski jednego mówiącego będą oceniać różnie (np. będą jednej masce przypisywać bardziej pozytywne cechy osobowościowe niż drugiej) (Chromý 2009, 256 - tłum. W.H.).

Ewentualne odmienne oceny powinny zaś odpowiadać różnicom w ocenie wykorzystanej w eksperymencie pary języków. Wynika to oczywiście z faktu, że jest to jedyna różnica dotycząca masek jednego autora wypowiedzi.

Tego typu eksperymenty przeprowadzane na terenach o stosunkowo powszechnej (czy też zakładanej) wielojęzyczności lub dyglosji odpowiadaja doskonale sytuacji językowej Górnego Śląska. Pierwotnie eksperyment

${ }^{15}$ Brak zakorzenienia polskojęzycznego ekwiwalentu terminu w rodzimej tradycji językoznawczej skłania do zastosowania niewielkiej modyfikacji. Zgodnie z anglojęzycznym oryginałem (por. Lambert 1967) oraz czeskim odpowiednikiem należałoby mówić o dopasowanych czy spojonych maskach (rolach). Ponieważ jednak idea eksperymentu jest badanie reakcji na zmianę - czyli przybranie - językowej maski takie tłumaczenie uznaję za trafniejsze, mając jednocześnie świadomość jego pewnego oddalenia od pierwowzoru. 
Lamberta wiązał się z sytuacją językową Quebecu. W kontekście czeskim Chromý wskazuje natomiast na zasadność zastosowania techniki w kontekście m.in. różnic w ocenach odmiennych środków określonych wariantów języka, postaw wobec języka, zjawisk code-switching i code-mixing, różnic w ocenach w zależności od kontekstu sytuacyjnego, ale także - co szczególnie interesujące w odniesieniu do Górnego Śląska - językowej dyskryminacji względem pochodzenia oceniających. Zweryfikowanie realnej postawy wobec śląszczyzny osób mających z nią codzienny kontakt, a także osób deklarujących jej wykorzystywanie da szansę na obiektywną ocenę efektywności podjętych działań emancypacyjnych oraz ewentualne ich korygowanie, podobnie jak niezwykle ważne byłoby również sprawdzenie postaw wobec rozpowszechniającego się wariantu pisanego.

Ukończenie prac korpusowych, precyzyjne wskazanie miejsca śląszczyzny na mapie słowiańskiej przestrzeni językowej (a sekundarnie także ukazanie jej realnej pozycji względem polszczyzny) oraz obiektywne zweryfikowanie jej wartości dla rodzimych użytkowników wydaje się najważniejszym wyzwaniem silezjanistycznie zorientowanej lingwistyki. Dzięki temu bowiem możliwe stanie się nie tylko prowadzenie zaawansowanych badań nad kulturą niematerialną Górnego Śląska, ale przede wszystkim umożliwi to jeszcze dalej posuniętą obiektywizację wyników.

\section{Literatura}

Balowska G., 2006, Problematyka czesz̧çyzny potocznej nieliterackiej (tzw. „obecná čšstina”) na lamach

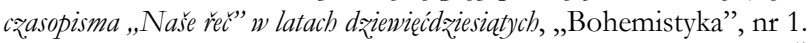

Bayerová-Nerlichová L., 2004, Jasykový úzus vs. postoj k jasykeu v Céchách: výsledky empirickébo a sociolingvistickébo výzkumu v západních Céchách a Praze, „Slovo a slovesnost”, č. 65.

Chromý J., 2009, Language attitudes, matched-guise technique and the Cžech lanuguage, „Naše Řeč”, vol. 9 , issue 5 .

Czesak A., 2008, Różnice jezylkowe w kontekstach politycznych i bumanistycznych, „Kultura i Polityka”, nr $2 / 3$.

Dalewska-Greń H., 1997, Jezyyki stowiańskie, Warszawa.

Daneš F., 1999, Postoje a hodnoticí kritéria prí kodifikaci, in: Uličný O., ed., Jasyk a text I. Výbor z lingvistickébo díla Františka Daneše, č. 2, Praha.

Golubović J., Gooskens Ch., 2015, Mutual intelligibility between West and South Slavic languages, "Russian Linguistics", no. 39.

Hofmański W., 2014, Transfer ujemny a kompetencja jezylkowa. Jezylk polski w nauczaniu Stowian, Praga.

Kadłubek Z., Staniczkowa L., 2011, red., 99 ksiażek, çyli mały kanon górnoślaski, Katowice.

Kadłubek Z., 2008, Listy z. Rzymu, Katowice. 
Lambert W., 1967, A Social Psychology of Bilingualism, "Journal of Social Issues", no. 23.

Michna E., 2008, Ślaskie i karpackorusinskie dylematy tożsamościowe. Aspiracje narodowe ślaskich i karpackorusinskkich liderów etnicznych. Próba analizy porównawczej, w: Sakson A., red., Ślazacy, Kaszubi, Mazurzy i Warmiacy. Między polskościq a niemieckościq, Poznań.

Michna E., 2014, Odrębnośc jezykowa matych grup etnicznych i jej rola w procesach walki o uznanie oraz. polityce tożsamości. Analiza porównawcza sytuacji Rusinów Karpackich i Ślazaków, „Studia Humanistyczne AGH", t. 13/3.

Murrmann J., 2014, Wielojezyczność jako źródto cierpień? Pozytywy i negatywy roz̧budowanych kompetencii jezykowych z.perspek.tywy spotecznej i lingwistycznej, ,Socjolingwistyka”, nr 28.

Nekvapil J., Sloboda M., Wagner P., 2009, Mnohojazyčnost v Ceské republice. Základní informace, Praha.

Nerlich L., 2009, Konzervativní, či liberálni př̌stup ke českému jazykovému standardu? Výsledky sondy mezi mladymi českými lingvisty na Univerzitě Řezno, „Naše řeč”, č. 92.

Niedźwiecka N., 2009, Etniczny aspekt tożsamości Łużyczan, Katowice.

Pospiszil K., 2016, Swojskość i utrata. Obrazy Górnego Ślaska w literaturze polskiej i czeskiej po 1989 roku, Katowice.

Siatkowska E., 1992, Rodzina jezyków zachodniostowiańskich, Warszawa.

Szmeja M., 2017, Ślask - bez. zmian(?). Ludzie, kultura i społeczność Ślaska w perspektywie postkolonialnej, Kraków.

Tambor J., 2006, Mowa Górnoślazaków oraz ich świadomość jezylkowa i etniczna, Katowice.

Tambor J., 2015, Stylizacja - pomyst na reaktywacje ślaszczyzny, „Poznańskie Studia Slawistyczne", nr 8 .

Wyderka B., 2014, Jezyke, dialekt czy kereol?, w: Nijakowski L.M., red., Nadciagaja Ślazacy. Czy istnieje narodowość slaska?, Warszawa. 